\title{
Cardiac biomarkers for early diagnosis of acute myocardial infarction: a literature review
}

Adrielle Nunes de Andrade Silva ${ }^{1}$; Orlando Augusto de Morais Miranda ${ }^{2}$; Dayana Correia de Almeida $^{3}$, Luciano Lins Júnior ${ }^{4}$; Mateus Henrique Aragão de Sales ${ }^{5}$; Ãndria Beatriz Félix de Araújo $0^{6}$; Andriele Lais da Silva Xavier ${ }^{7}$; Chantilly Geanne Conceição dos Santos ${ }^{8}$; Severina Patrícia da Silva ${ }^{9}$; Angela Maria da Silva ${ }^{10}$; Rosana Ferreira da Silva ${ }^{11}$; Natiane Carolaine da Silva ${ }^{12}$; Samia Dayana Lemos de Lacerda ${ }^{13}$ Thiago David dos Santos Silva*14

1 Biomedical by the Academic Center of Vitória de Santo Antão - UNIVISA.

2 Biomedical by the Academic Center of Vitória de Santo Antão - UNIVISA.

3 Undergraduate of the Bachelor of Pharmacy Course at the University Center UNIFACOL

4 Bachelor of Pharmacy University Center UNIFACOL.

5 Nurse, Postgraduate in Urgency and Emergency and ICU.

6 Undergraduate of the bachelor's degree in Pharmacy at the Academic Center of Vitória de Santo Antão - UNIVISA.

7 Undergraduate of the bachelor's degree in Pharmacy at the Academic Center of Vitória de Santo Antão - UNIVISA.

8 Undergraduate of the bachelor's degree in Pharmacy at the Academic Center of Vitória de Santo Antão - UNIVISA.

9 Undergraduate of the bachelor's degree in Pharmacy at the Academic Center of Vitória de Santo Antão - UNIVISA.

10 Undergraduate of the bachelor's degree in Pharmacy at the Academic Center of Vitória de Santo Antão - UNIVISA.

11 Undergraduate of the bachelor's degree in Pharmacy at the Academic Center of Vitória de Santo Antão - UNIVISA.

12 Undergraduate of the bachelor's degree in Pharmacy at the Academic Center of Vitória de Santo Antão - UNIVISA.

13 Master in Human Health and Environment - UFPE

14 Pharmacist, professor of the health center of the University Center UNIFACOL - UNIFACOL.

E-mail adresses: dayanacorreia18@gmail.com (Dayana Correia de Almeida), lucianolinsjr@hotmail.com (Luciano Lins Júnior), mateus-cbjrbr@hotmail.com (Mateus Henrique Aragão de Sales), andria.201919016@univisa.edu.br (Ãndria Beatriz Félix de Araújo) andriele.201819032@univisa.edu.br (Andriele Lais da Silva Xavier), chantillygeanne@hotmail.com (Chantilly Geanne Conceição dos Santos) patysilva81@hotmail.com (Severina Patrícia da Silva), angelajunho1977@gmail.com (Angela Maria da Silva), rosanaferreira1308@gmail.com (Rosana Ferreira da Silva), natianecarolaine07@gmail.com (Natiane Carolaine da Silva), samia.lacerda@ufpe.br (Samia Dayana Lemos de Lacerda), thiagodavid_10@hotmail.com (Thiago David dos Santos Silva)

${ }^{*}$ Corresponding author

\section{To cite this article:}

Silva, A.N.A.; Miranda, O.A.M.; Almeida, D.C.; Júnior, L.L.; Sales, M.H.A.; Araújo, A.B.F.; Xavier, A.L.S.; Santos C.G.C.; Silva. S.P.; Silva, A.M.; Silva, R.F.; Silva, N.C.; Lacerda, S.D.L; Silva, T.D.S. Cardiac biomarkers for early diagnosis of acute myocardial infarction: a literature review. International Journal of Sciences. Vol. 2, No. 1, 2021, pp. 18-21. ISSN 2763-5392.

Received: 06 29, 2021; Accepted: 06 30, 2021; Published: 07 15, 2021

\begin{abstract}
Acute Myocardial Infarction (AMI) known as heart attack is one of the main cardiovascular pathologies in Brazil, being caused by genetic and environmental factors. Aiming at the diagnosis in the first symptoms of the disease, biomarkers have become a useful tool. Present a literature review to identify cardiac biomarkers used in the diagnosis of Acute Myocardial Infarction. This is a literature review using the descriptors "Cardiac Biomarkers", "Diagnosis" AND "Acute Myocardial Infarction" in the VHL, LILACS, PubMed and SCIELO databases. Enzymes are responsible for biological reactions, they together with proteins are used as markers for aim investigation. Creatine kinase fraction MB (CK-MB), Troponins, Myoglobin and Lactate dehydrogenase (LDH) can be cited. In view of the presented, it is identified that the use of cardiac biomarkers is indispensable for the early diagnosis of the first hours of myocardial lesions.
\end{abstract}

Keywords: Cardiac Biomarkers; Diagnosis; Acute myocardial infarction

\section{Introduction}

Acute Myocardial Infarction (AMI) also known as heart attack is identified as decreased blood flow, causing hypoxia and death of cardiac tissue (VIANA et al, 2017). AMI is one of the leading causes of mortality in the world, and most clinical manifestations occur in the first hour of the onset of the disease, about $40 \%$ to $65 \%$ and approximately $80 \%$ in the 
first 24 hours (AYDIN et al., 2019).

The initial evaluation of MEI is based on clinical investigation, which allows effective treatment and assists in the prevention of adverse progression of acute myocardial infarction, resulting in a better quality of life of patients. Laboratory analysis associated with symptomatology is growing, however alternative biomarkers have greater sensitivity to early myocardial injury (RASKOVALOVA et al., 2013).

Biomarkers are important to establish the diagnosis and prognosis of diseases with greater accuracy. The rapid expansion of research has been stimulated by the development of molecular biology techniques. Other markers present different pathophysiological axes considered powerful instruments for the diagnosis and risk stratification in patients with AMI (MARTINEZ et al., 2019).

When cardiac lesions occur, the values of serum levels of these markers increase due to the release of cellular constituents into the bloodstream, such as enzymes, proteins and myoglobin. That do not allow you to specify the type and what caused the cellular damage. With the advancement of medicine and laboratory experiments it is possible to identify cardiac markers after an individual suffers infarction within 2 to 7 hours. Cardiac filaments can be found in the following enzymes: Troponins, Protein C, Myoglobin, Creatine kinase and Lactate dehydrogenase (LDH) (ALENCAR et al., 2018).

However, not all markers are specific to AMI and can be found in other pathologies, so complementary tests are needed together with the individual's symptomatology to have an effective diagnosis (SOUZA et al., 2016).

In this sense, the aim of this article was to discuss cardiac biomarkers as well as the most specific and effective ones for the early diagnosis of acute myocardial infarction.

\section{Methodology}

This is a study with data collection from secondary sources, through a bibliographic survey and based on the experience experienced by the authors at the time of an integrative review.

For the survey of articles in the literature, a search was conducted in the following databases: Virtual Health Library (VHL), Latin American and Caribbean Literature on Health Sciences (LILACS), PubMed and Scientific Electronic Library Online (Scielo).

Twenty-three articles were obtained and 09 were excluded because they were not relevant to the theme. For the search of the articles, the following English-language descriptors "Cardiac Biomarkers", "Diagnosis" AND "Acute Myocardial Infarction" were used.

The inclusion criteria determined for the selection of articles were: texts available in full, articles Portuguese and English from 2003 to 2019; articles in full that portrayed the importance of diagnosis in the first hours of AMI through cardiac biomarkers, articles published and indexed in these databases in the last five years. Exclusion criteria were clinical cases, theses and opinions.

The analysis of the selected studies, in relation to the design of the research, was based on a comparative study between the authors, aiming at the most sensitive and specific biomarkers for the early diagnosis of AMI before the literature.

\section{Results}

Biochemical markers also known as cardiac biomarkers are a set of elements to diagnose various cardiac pathologies, including AMI. In the myocardium, macromolecules are found, presenting as proteins or enzymes. Through the increases in the levels of these markers, myocardial lesions can be indicated. However, it is not able to define the type of lesion and the size of it, nor the cause of cell lesions, thus it is necessary a multi professional analysis to verify the reason for the change in the levels of these indicators. (VIANA, et al. 2017).

\section{Troponins}

Troponins are cardiac proteins found in muscle and skeletal cells, forming a complex of three subunits: Troponin C (TnC), Troponin I (cTnI) and Troponin T (cTnT), such subunits are responsible for controlling the interaction of actin-dependent calcium and myosin. They are the most important for the diagnosis of IAM. (ALENCAR, et al, 2018).

Troponin $\mathrm{C}(\mathrm{TnC})$ has no cardiac specificity, as it contains the same troponin isoform found in smooth muscle, are bound to calcium. Troponin I (cTnI) are associated with actin express specific sequence of amino acids that differs from troponin I of skeletal muscle, so there is no release of cTnI after skeletal muscle tissue injury. However, Troponin T (cTnT) is completely distinct from skeletal muscle because they are encoded by different genes. Therefore, for the diagnosis of AMI, the most used isoforms are Troponins $\mathrm{T}$ and I (AYDIN, et al., 2019).

\section{Protein $\mathrm{C}$ reactive}

Protein $\mathrm{C}$ is synthesized in the liver, is represented as a nonspecific marker, appearing elevated in plasma in response to tissue damage, cellular necrosis and infections. It may be associated in several situations of the immune system. (MOTTA, 2003)

Currently, studies are being developed on the relationship of Protein C (CRP-t) in cardiac patients and healthy individuals through serum concentration, an acute phase inflammatory marker of plasma half-life. The biological role of CRP is not yet known, but there are reports of its elevation in the presence of arteriosclerosis plaques. In individuals with AMI, the increase in t-CRP levels is associated with the extension area of myocardial necrosis, being associated in higher cases of mortality in the first 6 months. (ALENCAR, et al. 2018).

\section{Creatinekine}

Total Creatine kinase (CK) is an enzyme that controls the synthesis and use of phosphate. It is a dimeric molecule, formed by two subunits (M and $\mathrm{B}$ ), originating three $\mathrm{BB}$ izoenzymes (CK-BB) and creatine kinase isoenzyme $\mathrm{MB}$ (CK-MB). For myocardial injury, ck-total protein is not specific, as the elevation may be due to other factors such as the use of medications, illicit drugs, acute or chronic muscle injury, or diseases that decrease protein levels. (SILVA and MORESCO, 2011). 
$\mathrm{CK}$ is formed by subunits $\mathrm{B}$ and $\mathrm{M}$, joining ck-mm (muscular), CK-BB (cerebral) and CK-MB (myocardial). CKMB is found mainly in cardiac tissue. The CK-MB dosage determines the enzymatic activity, the test detects its concentration, in addition to active and inactive enzymes, so the CK-MB test is more sensitive and reliable. (VIANA, et al., 2017).

The CK-MB increases activity in a period of 4-6 hours after the infarction, /in about 18 hours occurs its peak, shortly after returning to normal in 48 hours. It has a high sensitivity in diagnosis between $93 \%$ and $100 \%$ after 12 hours of symptom onset. It is recommended, that ck-mb collections be performed in every three to affirm or rule out the diagnosis of AMI in suspicious patients. (VIANA, et al., 2017).

CK-MB has currently been important to evaluate myocardial lesions after coronary intervention, when the slight increase in its concentration may be related to a higher probability of mortality. (MIRANDA and LIMA, 2014).

\section{Myoglobulin}

Myoglobin is found only in the muscles, but may appear in the bloodstream in the process of muscle injury. It is a protein that binds to iron and oxygen present in large numbers in the heart and skeletal muscle of animals. It is a sensitive biomarker for Acute Myocardial Infarction, but does not present specificity. She is quickly released during the injury over a 24-hour period. (AYDIN, et al., 2019).

The evaluation of myoglobin is more useful in the diagnosis of AMI in association with other cardiac markers, causing a result and a rapid determination of AMI, this level rises in patients with nonspecific chest pain or those with altered electrocardiogram. (VIANA, et al., 2017).

The method used is the human determination of myoglobin through immunological tests, such as ELISA. This marker may be elevated in individuals with renal failure, due to its elimination in glomeruli, thus limiting the diagnostic usefulness in patients at high risk of cardiovascular diseases. (VIANA, et al., 2017).

\section{Lactate dehydrogenase}

It is an enzyme present in all cells, found in the cytoplasm. Lactate dehydrogenase (LDH) activity exceeded the normal range between 24 to 48 hours after AMI reaches a peak in 3-6 days after normal levels return in 8 to 14 days. Total LDH, despite being sensitive, is not specific and may present false positives in individuals with: myocarditis, megaloblastic anemia, leukemia, liver diseases, various neoplasms. The use of LDH for the diagnosis of ASIA is no longer used, due to the emergence of more sensitive and specific markers of myocardial tissue. (ALENCAR, et al., 2018).

\section{Conclusions}

Given the data analyzed around acute myocardial infarction, it is necessary that clinical evaluation is essential in the follow-up of therapy, prevention and care are essential in the quality of life of patients with these conditions. In addition, it is essential to laboratory analysis, which has an indispensable role in the early investigation of the pathology.

Thus, diagnostics and prognoses offered by biomarkers have been presented as fundamental factors for the proper identification of the disease. In addition to the advance in research through molecular biology techniques, and other instruments that are important in contributing to the identification and care of patients with Acute Myocardial Infarction.

All this is feasible for efficacy and speed in the accuracy of this cardiac injury. Thus, assisting in the type of injury that is affecting. However, because there are biomarkers for other cardiac pathologies, it is necessary to perform these complementary tests through a multidisciplinary team that make a more effective evaluation.

It is concluded that, the faster and more accurate this diagnosis, the more accurate the chances of survival of the child and ensure a better quality of life, considering that these short-term results are essential for early therapy and prevention.

\section{References}

[1] ALENCAR, Taynara An de; BERNARDES, Juliana Vieira Frezza. A Influência dos Marcadores de Lesão Cardíaca no Diagnóstico do Infarto do Agudo do Miocárdio. Saber Científico, Porto Velho, v. 4, n. 3, p.1-9, nov. 2018.

[2] AYDIN, Suleyman et al. Biomarkers in acute myocardial infarction: current perspectives. Vascular Health and Risk Management, [s.1.], v. 15, p.1-10, jan. 2019. Dove Medical Press Ltd. http://dx.doi.org/10.2147/vhrm.s166157.

[3] BAKER, James O. et al. Cardiac myosin-binding protein C: a potential early biomarker of myocardial injury. Basic Research in Cardiology, [s.1.], v. 110, n. 3, p.1-14, 3 abr. 2015. Springer Nature. http://dx.doi.org/10.1007/s00395-015-0478-5.

[4] DAUBERT, Melissa; JEREMIAS, Allen. The utility of troponin measurement to detect myocardial infarction: review of the current findings. Vascular Health And Risk Management, New York, v. 107, n. 15, p.691-699, 30 jul. 2010.

[5] GE, Wen-han et al. Identification of Biomarkers for Early Diagnosis of Acute Myocardial Infarction. Journal of Cellular Biochemistry, China, v. 24, p.1-26, 20 jun. 2017.

[6] MARTINEZ, Paula F. et al. Biomarkers in Acute Myocardial Infarction Diagnosis and Prognosis. Arquivos Brasileiros de Cardiologia, [s.1.], p.40-41, 2019. GN1 Genesis Network. http://dx.doi.org/10.5935/abc.20190131.

[7] MELANDER, Olle et al. Novel and Conventional Biomarkers for Prediction of Incident Cardiovascular Events in the Community. American Medical Association, Boston, v. 302, n. 104, p.49-57, 01 jul. 2009.

[8] MIRANDA M.R; LIMA L.M; Marcadores bioquímicos do infarto agudo do miocárdio Rev Med Minas Gerais; v. 24 nº 1 p. 98-105, 2014.

[9] MOTTA, Valter T. Bioquímica clínica para laboratório: princípios e interpretações / Valter T. Motta - 4 ed. Porto Alegre: Editora Médica Missau; São Paulo: Robe Editorial, EDUCS Caxias do Sul, 2003.

[10] RASKOVALOVA, Tatiana et al. Diagnostic accuracy of 
4 Silva, A.N.A.; Miranda, O.A.M.; Almeida, D.C.; Júnior, L.L.; Sales, M.H.A.; Araújo, A.B.F.; Xavier, A.L.S.; Santos C.G.C.; Silva. S.P.; Silva, A.M.; Silva, R.F.; Silva, N.C.; Lacerda, S.D.L; Silva, T.D.S. Cardiac biomarkers for early diagnosis of acute myocardial...

combined cardiac troponin and copeptin assessment for early rule-out of myocardial infarction: a systematic review and meta-analysis. European Heart Journal: Acute Cardiovascular Care, [s.1.], v. 3, n. 1, p.18-27, 20 nov. 2013. SAGE Publications. http://dx.doi.org/10.1177/2048872613514015.

[11] SHAH, Anoop S. V.; FERRY, Amy V.; MILLS, Nicholas L.. Cardiac Biomarkers and the Diagnosis of Myocardial Infarction in Women. Current Cardiology Reports, [s.1.], v. 19, n. 5, p.1-10, 8 abr. 2017. Springer Science and Business Media LLC. http://dx.doi.org/10.1007/s11886-017-0839-9.

[12] TANG, Liang; CASAS, Justin. Quantification of cardiac biomarkers using label-free and multiplexed gold nanorod bioprobes for myocardial infarction diagnosis. Biosensors and Bioelectronics, [s.1.], v. 61, p.70-75, nov. 2014. Elsevier BV. http://dx.doi.org/10.1016/j.bios.2014.04.043.

[13] VIANA, Roseni Ribeiro; SOUZA, Mario Renê Sibut Mares de. Marcadores Bioquímicos no Infarto Agudo do Miocárdio. Revista Eletrônica Biociências, Biotecnologia e Saúde, Curitiba, v. 12, n. 8, p.27-34, ago. 2017.

[14] WANG, Xue-mei et al. Long non-coding RNAs H19, MALAT1 and MIAT as potential novel biomarkers for diagnosis of acute myocardial infarction. Biomedicine \& Pharmacotherapy, [s.l.], v. 118, p.109208-109214, out. 2019. Elsevier BV. http://dx.doi.org/10.1016/j.biopha.2019.109208. 